RAD Conference Proceedings, vol. 3, pp. 89-93, 2018

ISSN 2466-4626 (online) | DOI: 10.21175/RadProc.2018.19

www.rad-proceedings.org

\title{
RISK ANALYSIS AND ANNUAL EFFECTIVE DOSE DUE TO TERRESTRIAL AND COSMIC RADIATION IN THE REGION OF NIĞDE PROVINCE (TURKEY)
}

\author{
Mehmet Erdogan ${ }^{*}$, Kaan Manisa ${ }^{2}$, Hasan Bircan ${ }^{2}$, \\ İbrahim Çevik ${ }^{1}$, Nesli Bingöldağ ${ }^{3}$, Recep Biyik³ and Veysel Zedef 4
}

\author{
${ }^{1}$ Selçuk University, Science Faculty, Physics Department, Campus, Konya, Turkey \\ ${ }^{2}$ Dumlupinar University, Art and Science Faculty, Physics Department, Campus, Kütahya, Turkey \\ 3Turkish Atomic Energy Authority, Çekmece Nuclear Research and Training Center, İstanbul, Turkey \\ 4Selçuk University, Engineering Faculty, Mining Engineering Department, Konya, Turkey
}

\begin{abstract}
The radiation exposure for people and all living things is inevitable. Most of these exposures are due to natural sources. Terrestrial and cosmic radiation sources are the most important contribution to these exposures which originated from the fractionation of $U-238$, Th-232, gamma radiation of $K-40$ and high-energy cosmic particles incident on the earth's atmosphere. The main contribution to these exposures comes from terrestrial sources. Terrestrial radionuclides are found in various concentrations in the crust of the earth depending on geological conditions of the region. They also cause exposure risks externally due to their gamma-ray emissions. This study assesses the terrestrial and cosmic radiation dose rates from the naturally occurring radionuclides in the region of Niğde province of Turkey. The measurements were performed on the surface soil using NaI(Tl) scintillation type gamma-ray detector. The external annual effective doses and cancer risk for people living in the region are also calculated from such terrestrial and cosmic gamma radiation dose rates for each individual.
\end{abstract}

Key words: Natural Radiation, Terrestrial and Cosmic Radiation, Gamma Dose Rate, Annual Effective Dose, Cancer Risk, Niğde Province, Turkey

\section{INTRODUCTION}

Radiation is an energy emission that comes from a radioactive source and travels through space and may be able to penetrate various materials. Light, radio, and microwaves are types of radiation that are called nonionizing radiation. Cosmic rays, x-rays, gammarays, UV-rays (partly), alpha and beta particles and neutron are called ionizing radiation. Gamma photons are the most energetic photons in the electromagnetic spectrum. They are emitted from the nucleus of some unstable (radioactive) atoms. Also, all living organisms are subject to a lifelong ionizing radiation. Natural radiation includes external radiation, which are terrestrial and cosmic radiations, and internal radiation. The most important contribution to natural radiation exposures comes from radioactive nuclides that originated from the crust of earth. The naturally occurring radionuclides $\mathrm{U}-238$, Th-232 and $\mathrm{K}-40$ are the main sources of radiation in soil and rocks. The human body is exposed to the gamma radiation from external sources which are mainly radionuclides in the $\mathrm{U}-238$ and Th-232 natural radioactive series and gamma radiation of $\mathrm{K}-40$ radionuclide. These radionuclides are found in various concentrations depending on geological conditions of the region. They may cause external exposure risk due to their gamma- ray emission. They are also present in the human body and they irradiate various organs with alpha and beta particle radiations, as well as gamma electromagnetic radiation [1].

The paper shows results of the outdoor gamma dose rate in the region of Niğde province, the external annual effective doses and cancer risk for people living in the region. This study draws a general picture of the gamma radiation due to terrestrial and cosmic sources.

\section{Study AREa AND GeOlogical Setting}

The study region, Niğde province is surrounded by the provinces of Aksaray, Nevşehir, Kayseri, Adana, İçel and Konya in central Anatolia, Turkey. The region is also known as a part of the Cappadocia region. Its location is $37^{\circ} 25^{\prime} \mathrm{N}-38^{\circ} 58^{\prime} \mathrm{N}$ parallels and $33^{\circ} 10^{\prime} \mathrm{E}-$ $35^{\circ} 25^{\prime} \mathrm{E}$ meridians. The Niğde province has six subdistricts which are central of Niğde, Altunhisar, Bor, Çamardı, Çiftlik and Ulukışla. The region has high mountain sequences of the Aladağlar in the east, where the highest summit is Demirkazlk Mountain (3,756 m) and the Bolkarlar in the south, where the highest summit is Medetsiz Mountain (3,524 m). The Bolkarlar and Aladağlar are also parts of central Taurus Mountains in the Mediterranean region. Besides, the

*merdogan@selcuk.edu.tr 
M. Erdogan et al., Risk analysis and annual effective dose..., RAD Conf. Proc., vol. 3, 2018, 89-93

northwest region is covered with a caldera complex of Melendiz Mountain (2,963 m) in addition to volcanic structures of Hasan Mountain $(3,268 \mathrm{~m})$, Keçeboyduran Mountain $(2,727 \mathrm{~m})$ and Göllü Mountain (2,172 m) [2].

As for the geology of the region, in the study area, Upper Cretaceous to Middle Eocene aged magmaticvolcanic rocks and sedimentary rocks are widespread. Baş et al (1992) perhaps made most detailed and valuable work in between Ulukışla and Çamardı area. The authors named the magmatic rocks in the area as 'Ulukışla magmatits' and classified the plutonic rocks as diorite-gabbro and monzonite, the extrusive rocks as basalt-andesite, latite-andesite, latite and trachyte. Baş et al (1992) comments (based on the major and trace element results of the plutonic and volcanic rocks outcropped in the region) the rocks were produced by magmatic arc and the rocks were partly influenced by the mantle [3].

\section{Materials AND Method}

Outdoor terrestrial and cosmic gamma dose rates and the altitude of the each measurement location at 34 locations were measured in the region of Niğde (Figure 1) in the summer of 2017.

The measurements were performed for about 1 minute at a height of 1 meter above the surface soil using a portable survey meter (RadEye ${ }^{\mathrm{TM}}$ NBR High Sensitivity Gamma Radiation Monitor) connected with a plastic $\mathrm{NaI}(\mathrm{Tl})$ gamma ray scintillation detector [4]. The main function of the crystal is to convert gamma ray to the photons of visible light process called scintillation. Outdoor gamma dose rates (OGDR) in the air were measured as a unit of $\mu \mathrm{Sv} / \mathrm{h}$. Also, the annual effective dose equivalents (AEDE) were calculated using Equation 1 [5]. The annual effective dose equivalents in $\mu \mathrm{Sv} / \mathrm{h}$ include both of the cosmic ray and terrestrial components of the gamma radiation. In equation 1, DCF and OF are the dose conversion factor (DCF) from the absorbed dose to the effective dose and outdoor occupancy factor, respectively. [1]. As shown in Equations 1, the calculations for occupational factor and dose conversion factor are assumed to be 0.2 and 0.7 for adults according to the UNSCEAR 2000 datas [1].

$$
\operatorname{AEDE}=\operatorname{OGDR}(\mu \mathrm{Sv} / \mathrm{h}) \times \mathrm{OF}(0.2) \times \mathrm{T}(8760 \mathrm{~h})
$$

The estimation of lifetime cancer risk (LTCR) was calculated by equation (2):

\section{$\mathrm{ELCR}=\mathrm{AEDE} \times \mathrm{LE} \times \mathrm{RFSE}$}

LE is the lifetime expectancy at birth by Niğde province (78 years) [6], and RFSE is the risk factor for stochastic effects of the common population. The risk factor per Sievert is used as values of $0.05 \mathrm{~Sv}^{-1}$ according to the ICRP 1990 reports $[7,8]$.

\section{RESUlTS AND DisCUSSION}

In the study, we measured external outdoor gamma dose rate with the altitude of the each measurement location in the region of Niğde province of Turkey as shown Figure 1 and Table 1.

The results of the outdoor gamma dose rate due to terrestrial and cosmic radiation in Niğde region are varied from $0.04 \mu \mathrm{Sv} / \mathrm{h}$ (location\# 27) to $0.54 \mu \mathrm{Sv} / \mathrm{h}$ (location\# 24) for 72 locations as shown in Table 1 . The annual effective dose equivalent values and excess lifetime cancer risk for people living in the region were also calculated from such terrestrial and cosmic gamma radiation dose rates for each individual (Figure 2).

The main contribution to the calculated annual effective dose values comes from terrestrial sources. The average annual dose equivalent and excess lifetime cancer risk were calculated as $213.65 \mu \mathrm{Sv}$ and $7.48 \times$ $10^{-4}$, respectively. The average annual effective dose equivalent and excess lifetime cancer risk for people living in the region were found to be approximately three times higher than the world average of $0.07 \mathrm{mSv}$ (average worldwide exposure to external terrestrial radiation) and $2.45 \times 10^{-4}$, respectively [1]. Terrestrial and cosmic radiations depend on geological conditions and altitude of the region. In our opinion, the high gamma dose measurement locations could be resulted by two geological reasons. The first probability is that there have been some fault zones along such as either active or non-active (especially northwest and east of the region) and having mountains in volcanic structure (especially north-west of the region) the high concentration localities. And second reason could be the presence of thicker plutonic (granitic, monzogranitic) settlement below the higher radioactive concentration measurement points when compared to other localities. According to the results, the highest annual effective dose equivalent rate was found to be $946.08 \mu \mathrm{Sv}$ in the Bekçili village of Çamardı district of Niğde whose highest value of the absorbed dose is also in as shown Figure 1 and 2. It can be related that the village region takes place in the region of granitic area known as Central Anatolian Massif. Because of that, higher radiation levels are associated with igneous rocks, such as granite, and lower levels with sedimentary rocks; however, some shales and phosphate rocks have a relatively high content of radionuclides as an exception [1]. In addition to general reasons, this value can be related to the fact that Bekçili region is at the highest altitude since the gamma dose rate value also includes cosmic radiation. However, the measured gamma dose values in the region generally do not depend on the altitude of the locations.

It is possible to observe such situations in some other regions of Turkey. For example, while the annual effective dose equivalent value in Kütahya changes between $96.4 \mu \mathrm{Sv}$ (Çavdarhisar region) and 1091.2 $\mu \mathrm{Sv}$ (Simav region) [9], the average of this value for Artvin is $214.5 \mu \mathrm{Sv}$ [10] and for Ilgin district of Konya is $132.9 \mu \mathrm{Sv}$ [11]. The value for other countries is $740 \mu \mathrm{Sv}$ for Tehran (Iran) [12], $330 \mu \mathrm{Sv}$ for Selama district of Malaysia [13]. Besides, the average of cancer risk for some cities of Turkey and other countries was found to be $7.5 \times 10^{-4}$ in the study done in Artvin (Turkey) [10], $22.9 \times 10^{-4}$ in the region of Tehran (Iran) [12], $5.18 \times 10^{-4}$ in the region of Ilgin district of Konya 
M. Erdogan et al., Risk analysis and annual effective dose..., RAD Conf. Proc., vol. 3, 2018, 89-93

(Turkey) [11]. This value for Selama district of Malaysia

is about 5 times higher than the world average [13].

Table 1. Outdoor gamma dose rate, annual effective dose equivalent and lifetime cancer risk for people living in the region of Niğde.

\begin{tabular}{|c|c|c|c|c|c|c|}
\hline No & City/District & Location & $\begin{array}{l}\text { Altitude } \\
\text { (m) }\end{array}$ & $\begin{array}{l}\text { Gamma Dose } \\
\text { Rate }(\mu S v / h)\end{array}$ & $\begin{array}{c}\text { Annual Effective } \\
\text { Dose }(\mu \mathrm{Sv} / \mathrm{a})\end{array}$ & $\begin{array}{l}\text { ELCR Excess Lifetime } \\
\text { Cancer Risk x } 10^{-4}\end{array}$ \\
\hline 1 & Altunhisar & Akçaören & 1236 & 0.12 & 210.24 & 7.36 \\
\hline 2 & Altunhisar & Akçaören & 1236 & 0.12 & 210.24 & 7.36 \\
\hline 3 & Altunhisar & Centrum & 1236 & 0.12 & 210.24 & 7.36 \\
\hline 4 & Altunhisar & Centrum & 1236 & 0.12 & 210.24 & 7.36 \\
\hline 5 & Altunhisar & Uluören & 1510 & 0.11 & 192.72 & 6.75 \\
\hline 6 & Altunhisar & Uluören & 1510 & 0.12 & 210.24 & 7.36 \\
\hline 7 & Altunhisar & Uluören & 1550 & 0.16 & 280.32 & 9.8 \\
\hline 8 & Bor & Bereket & 1048 & 0.14 & 245.28 & 8.59 \\
\hline 9 & Bor & Bereket & 1050 & 0.22 & 385.44 & 13.49 \\
\hline 10 & Bor & Centrum & 1206 & 0.11 & 192.72 & 6.75 \\
\hline $\mathbf{1 1}$ & Bor & Centrum & 1206 & 0.08 & 140.16 & 4.91 \\
\hline 12 & Bor & Çukurkuyu & 1243 & 0.11 & 192.72 & 6.75 \\
\hline 13 & Bor & Çukurkuyu & 1243 & 0.07 & 122.64 & 4.29 \\
\hline 14 & Bor & Kaynarca & 1231 & 0.1 & 17.2 & 6.13 \\
\hline 15 & Bor & Kaynarca & 1231 & 0.08 & 140.16 & 4.91 \\
\hline 16 & Bor & Kemerhisar & 1089 & 0.09 & 157.68 & 5.52 \\
\hline 17 & Bor & Kemerhisar & 1089 & 0.09 & 157.68 & 5.52 \\
\hline 18 & Bor & Klavuz & 1443 & 0.07 & 122.64 & 4.29 \\
\hline 19 & Bor & Klavuz & 1443 & 0.07 & 122.64 & 4.29 \\
\hline 20 & Bor & Postallı & 1430 & 0.24 & 420.48 & 14.72 \\
\hline 21 & Bor & Postallı & 1430 & 0.11 & 192.72 & 6.75 \\
\hline 22 & Bor & Seslikaya & 1064 & 0.1 & 175.2 & 6.13 \\
\hline 23 & Bor & Seslikaya & 1064 & 0.1 & 175.2 & 6.13 \\
\hline 24 & Çamardı & Bekçili & 1968 & 0.54 & 946.08 & 33.11 \\
\hline 25 & Çamardı & Bekçili & 1600 & 0.09 & 157.68 & 5.52 \\
\hline 26 & Çamardı & Centrum & 1497 & 0.08 & 140.16 & 4.91 \\
\hline 27 & Çamardı & Demirkazık & 1545 & 0.04 & 70.08 & 2.45 \\
\hline 28 & Çamardı & Demirkazık & 1545 & 0.05 & 87.6 & 3.07 \\
\hline 29 & Çamardı & Üçkapılı & 1892 & 0.18 & 315.36 & 11.04 \\
\hline 30 & Çamardı & Üçkapılı & 1892 & 0.12 & 210,24 & $7 \cdot 36$ \\
\hline 31 & Çiftlik & Centrum & 1554 & 0.14 & 245.28 & 8.59 \\
\hline 32 & Çiftlik & Kula & 1568 & 0.15 & 262.8 & 9.20 \\
\hline 33 & Çiftlik & Kula & 1560 & 0.11 & 192.72 & 6.75 \\
\hline 34 & Niğde & Centrum & 1230 & 0.11 & 192.72 & 6.75 \\
\hline 35 & Niğde & Centrum & 1230 & 0.07 & 122.64 & 4.29 \\
\hline 36 & Niğde & Gölcük & 1310 & 0.13 & 227.76 & 7.97 \\
\hline 37 & Niğde & Gölcük & 1310 & 0.13 & 227.76 & 7.97 \\
\hline 38 & Niğde & İçmeli & 1480 & 0.23 & 402.96 & 14.10 \\
\hline 39 & Niğde & İnli & 1355 & 0.14 & 245.28 & 8.59 \\
\hline 40 & Niğde & İnli & 1355 & 0.14 & 245.28 & 8.59 \\
\hline 41 & Niğgde & Karaatlı & 1383 & 0.09 & 157.68 & 5.52 \\
\hline 42 & Niğde & Karaatlı & 1383 & 0.15 & 262.8 & 9.20 \\
\hline 43 & Niğde & Karaatlı & 1383 & 0.15 & 262.8 & 9.20 \\
\hline 44 & Niğde & Kömürcü & 1448 & 0.17 & 297.84 & 10.42 \\
\hline 45 & Niğde & Kömürcü & 1448 & 0.22 & 385.44 & 13.49 \\
\hline 46 & Niğde & Orhaneli & 1603 & 0.06 & 105.12 & 3.68 \\
\hline 47 & Niğde & Orhaneli & 1603 & 0.09 & 157.68 & 5.52 \\
\hline 48 & Niğde & Tepeköy & 1332 & 0.13 & 227.76 & 7.20 \\
\hline 49 & Niğde & Tepeköy & 1332 & 0.15 & 262.8 & 9.20 \\
\hline 50 & Niğde & Uluağaç & 1440 & 0.05 & 87.6 & 3.07 \\
\hline 51 & Niğde & Uluağaç & 1440 & 0.09 & 157.68 & 5.52 \\
\hline 52 & Ulukışla & Centrum & 1490 & 0.11 & 192.72 & 6.75 \\
\hline 53 & Ulukışla & Centrum & 1490 & 0.19 & 332.88 & 11.65 \\
\hline 54 & Ulukışla & Çanakçı & 1410 & 0.18 & 315.36 & 11.04 \\
\hline 55 & Ulukışla & Çanakçı & 1410 & 0.28 & 490.56 & 17.17 \\
\hline 56 & Ulukıșla & Çiftehan & 1006 & 0.09 & 157.68 & 5.52 \\
\hline 57 & Ulukışla & Çiftehan & 1006 & 0.09 & 157.68 & $5 \cdot 52$ \\
\hline 58 & Ulukışla & Çiftehan & 1006 & 0.09 & 157.68 & $5 \cdot 52$ \\
\hline 59 & Ulukışla & Darboğaz & 1331 & 0.05 & 87.6 & 3.07 \\
\hline 60 & Ulukışla & Darboğaz & 1331 & 0.13 & 227.76 & 7.97 \\
\hline 61 & Ulukışla & Eminlik & 1368 & 0.1 & 175.2 & 6.13 \\
\hline 62 & Ulukışla & Eminlik & 1368 & 0.1 & 175.2 & 6.13 \\
\hline 63 & Ulukıșla & Güney & 1331 & 0.15 & 262.8 & 9.20 \\
\hline 64 & Ulukışla & Güney & 1331 & 0.11 & 192.72 & 6.75 \\
\hline 65 & Ulukışla & Ovacık & 1434 & 0.11 & 192.72 & 6.75 \\
\hline 66 & Ulukışla & Ovaclk & 1434 & 0.11 & 192.72 & 6.75 \\
\hline 67 & Ulukışla & Tekneçukuru & 1386 & 0.11 & 192.72 & 6.75 \\
\hline 68 & Ulukışla & Tekneçukuru & 1386 & 0.1 & 175.2 & 6.13 \\
\hline 69 & Ulukıșla & Tepeköy & 1255 & 0.05 & 87.6 & 3.07 \\
\hline 70 & Ulukışla & Tepeköy & 1255 & 0.06 & 105.12 & 3.68 \\
\hline 71 & Ulukıșla & Yeniyıldız & 1542 & 0.06 & 105.12 & 3.68 \\
\hline 72 & Ulukıșla & Yeniyıldız & 1542 & 0.06 & 105.12 & 3.68 \\
\hline
\end{tabular}




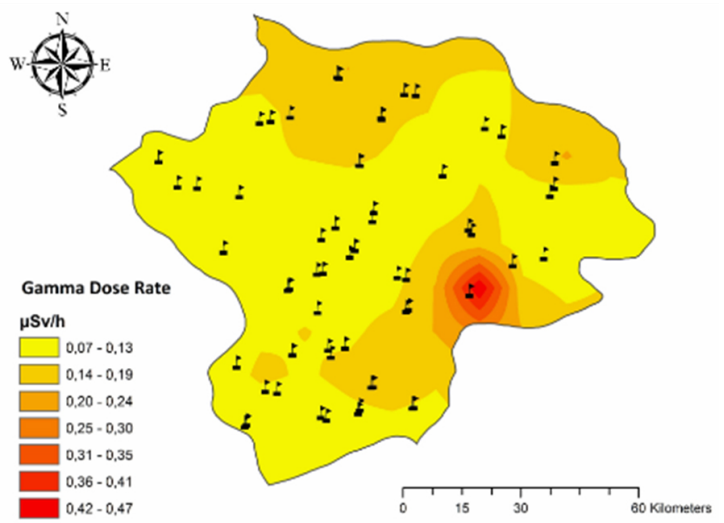

Figure 1. Gamma dose rate distribution in the study region

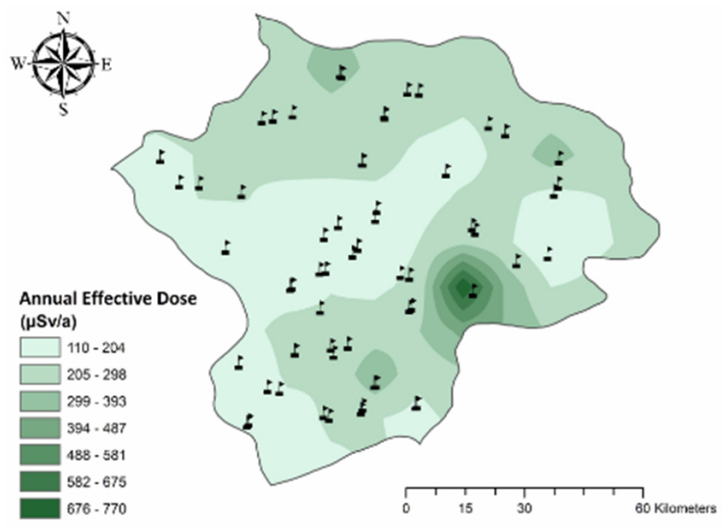

Figure 2. Annual effective dose value distribution for the people living in the region

\section{CONCLUSION}

In this study, we measured the terrestrial and cosmic radiation dose rates from the naturally occurring radionuclides in the region of Niğde province of Turkey. The average annual effective dose equivalent and excess lifetime cancer risk for people living in the region were found to be $213.65 \mu \mathrm{Sv}$ and $7.48 \times 10^{-4}$, respectively. These values are approximately three times higher in comparison to the world average. This situation can be related to the fact that the study area has some active and non-active fault zones, thicker plutonic settlement and volcanic and high altitude mountains. For this reason, these measurements and risk analyses should be repeated in this region in the years to come.

Acknowledgements: This study was supported by Turkish Atomic Energy Authority (TAEA) with the protocol signed between Selçuk University and TAEA.

\section{REFERENCES}

1. Sources and effects of ionizing radiation, vol. 1, Annex B, UNSCEAR, New York (NY), USA, 2000, pp. $84-154$.

Retrieved from: http://www.unscear.org/docs/publicat ions/2000/UNSCEAR 2000 Report Vol.I.pdf; Retrieved on: Aug. 10, 2018

2. A. C. Demirkesen, "Quantifying geological structures of the Niğde province in central Anatolia, Turkey using SRTM DEM data," Environ. Geol., vol. 56, no. 5, pp. $865-875$, Jan. 2009.

DOI: 10.1007/s00254-008-1187-2

3. H. Baş, N. Poyraz, D. Jung, "Ulukişla-çamardi (Niğde) magmatîtlerînin petrografisi ve jeokimyasi," Türkiye Jeoloji Bülteni, vol. 35, pp. 71 - 89, Aug. 1992. (H. Baş, N. Poyraz, D. Jung, "Petrography and geochemistry of the Ulukışla-Çamardı (Niğde) magmatites," Geol. Bull. Turkey, vol. 35, pp. $71-89$, Aug. 1992.)

Retrieved from: http://www.jmo.org.tr/resimler/ekler/ e2eecgca19c0767 ek.pdf?dergi=TURKIYEJEOLOJIBU LTENI;

Retrieved on: Aug. 10, 2018

4. RadEye ${ }^{\mathrm{TM}}$ NBR High Sensitivity Gamma Radiation Monitor, Fisher Scientific, Pittsburg (PA), USA, 2018. Retrieved from: https://www.fishersci.com/shop/prod ucts/thermo-scientific-radeye-nbr-high-sensitivitygamma-radiation-monitor-radeye-nbr-high-sensitivitygamma-radiation-monitor/19155223;

Retrieved on: Jun. 12, 2018

5. M. Boutillon, A. M. Perroche-Roux, "Re-evaluation of the W value for electrons in dry air," Phys. Med. Biol., vol. 32, no. 2, pp. $213-219$, Apr. 1987. DOI: $10.1088 / 0031-9155 / 32 / 2 / 005$

6. Turkish statistical institute official web page, Turkish statistical institute, Ankara, Turkey, 2018.

Retrieved from: www.turkstat.gov.tr; Retrieved on: Jun. 12, 2018

7. 1990 recommendations of the international commission on radiological protection, ICRP Publication 6o, ICRP, Ottawa, Canada, 1990. PMid: 2053748

8. S. Luevano-Gurrola et al., "Lifetime Effecttive Dose Assesment Based on Background Outdoor Gamma Exposure in Chihuahua City, Mexico," Int. J. Environ. Res. Public Health, vol. 12, no. 10, pp. 12324 - 12339, Oct. 2015.

DOI: $10.3390 /$ ijerph121012324

PMid: 26437425

PMCid: PMC4626971

9. L. Sahin et al., "Assessment of radiological hazard parameters due to natural radioactivity in soils from granite-rich regions in Kütahya province, Turkey," Isot. Environ. Health Stud., vol. 53, no. 2, pp. 212 - 221, May 2017.

DOI: $10.1080 / 10256016.2016 .1207640$ PMid: 27465510

10. Y. Kobya, H. Taskin, C. M. Yesilkanat, U. Cevik, "Evaluation of outdoor gamma dose rate and cancer risk in Artvin province, Turkey," Hum. Ecol. Risk Assess., vol. 21, no. 8, pp. 2077 - 2085, Nov. 2015. DOI: $10.1080 / 10807039.2015 .1017876$

11. M. Erdogan, K. Manisa, "Assesment of Outdoor Terrestrial Gamma Dose Rates in the Konya-IlgınÇavuşçu Lignite Deposit (Turkey)," Süleyman Demirel University Journal of Science, vol. 11, no. 2, pp. 89 - 93, Nov. 2016.

Retrieved from: http://dergipark.gov.tr/download/artic le-file/274645;

Retrieved on: Aug. 10, 2018 
M. Erdogan et al., Risk analysis and annual effective dose..., RAD Conf. Proc., vol. 3, 2018, 89-93

12. A. Eslami et al., "Outdoor gamma radiation measurment in order to estimate the annual effective dose and excess lifetime cancer risk for residents of Tehran Iran," J. Air Pollution and Health, vol. 1, no. 4, pp. $243-250$, Dec. 2016.

Retrieved from: http://japh.tums.ac.ir/index.php/japh /article/view/65/37;
Retrieved on: Aug. 10, 2017

13. A. T. Ramli, N. H. Apriantoro, H. Wagiran, "Assessment of radiation dose rates in the high terrestrial gamma radiation area of Selama district, Perak, Malaysia," Appl. Phys. Res., vol. 1, no. 2, pp. 45 - 52, Nov. 2009. DOI: 10.5539/apr.v1n2p45 